$\overline{\overline{\text { BRUSSELS }}} \overline{\overline{\text { STUDIES }}}$

\section{Brussels Studies}

La revue scientifique électronique pour les recherches sur Bruxelles / Het elektronisch wetenschappelijk tijdschrift voor onderzoek over Brussel / The e-journal for academic research on Brussels

Notes de synthèse | 2009

\title{
The institutions of Brussels
}

\section{Synopsis, CFB No. 14}

De Brusselse instellingen

Les institutions bruxelloises

\section{Pascal Delwit and Kris Deschouwer}

Translator. Mike Bramley

\section{OpenEdition \\ Journals}

\section{Electronic version}

URL: http://journals.openedition.org/brussels/1001

DOI: 10.4000/brussels.1001

ISSN: 2031-0293

\section{Publisher}

Université Saint-Louis Bruxelles

\section{Electronic reference}

Pascal Delwit and Kris Deschouwer, «The institutions of Brussels », Brussels Studies [Online]

Synopses, Online since 24 February 2009, connection on 03 May 2019. URL : http:// journals.openedition.org/brussels/1001; DOI : 10.4000/brussels. 1001 
www.brusselsstudies.be

\author{
ÉTATS GÉNÉRAUX DE \\ STATEN-GENERAAL VAN \\ CITIZENS'FORUM OF \\ RUXELLES \\ RUSSEL \\ RUSSELS \\ www.citizensforumofbrussels.be
}

Synopsis nr. 14

\section{The institutions of Brussels}

\section{P. Delwit, K. Deschouwer}

Translation: Mike Bramley

- Pascal Delwit is Professor of Political Science at the Université libre de Bruxelles. His research focuses on political parties in Belgium and Europe. Pascal DELWIT, Emilie VAN HAUTE (eds.), Le vote des Belges (Bruxelles - Wallonie, 10 juin 2007), Bruxelles, Editions de l'Université de Bruxelles, collection Science Politique, 2008. Contact : pdelwit@ulb.ac.be, 026503903

- Kris Deschouwer is a Professor within the Department of Political Science at the Vrije Universiteit Brussel. His research focuses on the political representation of parties in complex political systems. Deschouwer, K. (2009), "Coalition formation in multi-level settings: Belgium 1995-2008", Regional and Federal Studies, vol 19, no 1, p. 13-35

Contact : Kris.Deschouwer@vub.ac.be, 026292059

Conference-debate:

2 March, 19.45

Flagey

Place Sainte-Croix 1050 Brussels 


\section{Observations}

The present statute of Brussels is not the result of a conscious choice and seems more akin to the statute of Belgium in general, as no one wanted it to be this way. No one has ever striven for this Brussels as a desirable solution.

The institutions of Belgium and Brussels are built on the linguistic frontier established in 1963 (with discussion about the question of whether this frontier can still change), on a territorial agreement concerning language use (excluding the language frontier and surrounding Brussels), and on the systematic separation of the two large language communities. Brussels is an essential part of the Belgian compromise concerning the territorial reorganisation of the area.

\section{Regions and Communities}

This place that Brussels has in the Belgian compromise is manifested in the first instance in the presence of institutions that relate to regional matters, and those that relate to communities. The double federation of regions and communities that Belgium has become is also not the implementation of a blueprint, but an answer to two different visions about the territorial organisation of the country. Both regions and communities were established in 1970, precisely because of the location of Brussels and also because of the evolution of language use in Brussels. The preference for communities on the Flemish side presumed that Brussels would also belong to the Flemish Community. The preference for regions on the French-speaking side was inspired by the desire for Brussels not to belong to Flanders, but to exist in its own right, as a region 'à part entière'. In Brussels, the institutions of the Region, the Flemish Community Commission (VGC), the French Community Commission (COCOF) and the Common Community Commission (GGC/COCON) arise from the double Belgian federation. 
The question of Brussels has always weighed heavily on the institutional debates, with 'highlights' such as the failure of the Egmont Pact and the Stuyvenberg Agreement in 1977-78 and the decision in 1980 to put Brussels 'on the back burner' until the compromise of 1988. It always concerned the borders of Brussels and what this signified, the regional statute and the position and role of the Dutch-speaking minority in the region. Ultimately, a complexly structured Brussels Capital Region was established, the rightful existence of which as a fully-fledged region is still questioned by the majority of Flemish politicians, and the borders of which are still questioned by the majority of French-speaking politicians.

The different visions that both language groups have about the position of Brussels in the Belgian institutions also translates in the asymmetry between the French Community Commission and the Flemish Community Commission, such that the French Community Commission is an independent legislative institution while the Flemish Community Commission is part of the Flemish Community (in Belgium).

\section{The region and the municipalities}

With the tensions about language and language use in the background, a number of institutional debates were actually either not carried out or nervously avoided in Brussels. This was particularly the case at the municipal level. Brussels was not involved in the great amalgamation operation of 1976 as no acceptable solution could be found at that time. The debate about the amalgamations in Belgium focused on local governing power, efficiency and also on economies of scale. At that time, there was still no clarity in Brussels about the statute of the region itself, such that no meaningful discussion could be held about the position of the municipalities within it.

On the Flemish side, a request was sounded about restricting the number of municipalities, possibly even to one single municipality. This request was partly inspired by the observation that the Dutch-speaking presence is very small in many municipalities, and that successful protection for the minority could only be extended in a larger entity. At that time, the communautaire inspiration of proposals about the municipal level ensured the absence of any rational debate about it.

However, a debate was forced through about the configuration of the Brussels municipalities and the division of powers between municipalities and region, partly due to the fact that ideas about urban policy had changed in the meantime and also due to the reality of the municipal landscape in Brussels. This municipal landscape is particularly varied on at least three levels: the wealth of the municipalities, their size and their demography (see table 1).

In terms of wealth, the variation is enormous. As the poorest municipality in the country, Sint-Joost only manages to achieve half the welfare index of the municipalities in Belgium, whilst seven Brussels municipalities come out above the average of 100. It goes without saying that this configuration has an impact on incomes and therefore also on the municipalities' expenses.

In terms of the size of the municipalities, the variation is less extensive. The largest municipality (Brussels) is 29.6 times larger than the smallest (Sint-Joost). There are also six municipalities that are smaller than $5 \mathrm{~km}^{2}$ and four that are larger than 15 $\mathrm{km}^{2}$. 
The differences in population size are considerable. There are 7.83 times more inhabitants in the largest municipality (Brussels) than in the smallest (Koekelberg), and the population density in Sint-Joost is 10.8 times larger than in WatermaalBosvoorde. Furthermore, these figures only take account of the population that is effectively listed in the municipalities' population registers.

With such differences and variation between the municipalities within such a small urban area, the question emerges of whether the municipal level can really continue to be organised in the same way as classical municipalities in Belgium.

\section{Political representation}

The history of Belgium was a dominant factor in the search for both regional and municipal institutions. Differing visions about language and language use lie at the origin of the Brussels Capital Region and are visible in its institutions and borders. The complex and hybrid institutions of the Brussels Capital Region are therefore largely constructed on the difference between two language groups. Both are neatly separated from each other - also in the organisation of elections - and then mandatorily brought together for the collaborative governance of the city. In this way, Brussels very much resembles Belgium, where the same principles of strict separation and mandatory collaboration are also applied. 


\section{Questions-issues}

The most important problems that arise in relation to the institutions of Brussels relate to their lack of connection to the urban and regional reality of the $21^{\text {st }}$ century. The weight of history has also led to institutions that provide an answer to the data and problems of a number of decades ago. On the other hand, it would be impossible to just think away the attention that is paid to language and language use and to the unequal relationships between the languages.

\section{Political representation}

The Brussels Capital Region is defined as a region that comprises two groups that clearly differ from each other because they speak a different language. This point of departure is problematic on at least two levels. In the first instance, there is the strict border that separates the two language groups from each other. This presumes that it is both possible and relevant for all inhabitants of Brussels to be distinguished as belonging to either one or the other. A grey zone or an absence of a choice can not be translated institutionally. This is particularly well illustrated in the Parliamentary elections for the Brussels Capital Region. A political movement that wishes to align itself to all inhabitants of the region is not able to do so. The experience with the elections for the Agglomeration council in 1971 - where the guarantees for sufficient Dutch-speaking representation were not binding and could therefore be conveniently skirted around - ensured that the possibility of bilingual lists for the election of the Brussels representatives was not maintained and that a candidate must make a one-off permanent language choice. Today, the parties generally align themselves to their own language group, even though the majority of Dutch-speaking parties also communicate with the French-speaking voters and even though part of the population feels ambivalent towards belonging to one of the communities or that it is unimportant.

This model therefore differs from the way in which elections are organised at the municipal level and has led to an unusual compromise about the composition of the Brussels Parliament. At 89, the number of representatives is undoubtedly too great in absolute terms. However, this is a result of the desire to have a sound parliamentary representation for the Dutch-speakers and to retain a certain link between the size of the communities and their parliamentary strength.

This rigid separation of the population into two language groups is also problematic for a second reason. The division in language groups is only relevant for inhabitants of Belgian origin. Over the past decades, Brussels has become increasingly more diversified and internationalised in terms of the composition of its population. For an increasing number of Brussels residents, institutions built on the (contrast between the) Belgian language groups is not really adequate. This is very important, as it is very much a 'blind spot' in the debates about Brussels and goes hand in hand with a second problem. Precisely because of the very specific composition of the population in the Brussels Capital Region, a large group of inhabitants do not possess the right to vote. We must also not forget that around $28 \%$ of the Brussels population do not have Belgian nationality. On the one hand, this tempers the 'mismatch' between the institutions and the composition of the population, but it particularly presents Brussels with a very significant problem of democratic legitimacy. 


\section{Region and community}

Powers that belong to the communities are language-related within the context of Belgium. They also do not belong to the collection of powers of the Brussels Capital Region. This raises the question of whether community powers should be assigned to Brussels in order to maintain effective and coherent management of the capital region. Is it possible for the region to put itself on the international map if it is not responsible for tourism? Is it possible for powers relating to the economy and the employment market - which may become more extensive in the future - to have sufficient effect when they have no link with educational powers? The question can also be raised as to whether it should be and remain impossible for the Brussels Capital Region to implement policies relating to culture, welfare, healthcare, social integration, etc. The taboos and the angst concerning minorisation are prevalent here.

\section{The region and the municipalities}

The organisation and working of the municipalities in the Brussels Capital Region still reflect the choices that were made a long time ago for all Belgian municipalities, long before there was any mention of decentralisation to regions and communities. Only marginal amendments have been added, including guarantees for Dutchspeakers. The exceptional creativity that the Belgian and Brussels political elites have displayed in finding solutions to communautair-loaded tensions contrasts sharply with the lack of creativity and boldness when faced with the organisation of the municipal level. This lack of boldness could also be the result of the lack of independence on the regional level with regard to the municipal level. Most members of the Brussels Capital Parliament also posses a mandate as a local councillor, alderman or mayor. In this way, they are part of both their own custodial government and the government which possibly needs to redefine their local mandate or its meaning. 


\section{Policy options}

Possible options for alterations and improvements to the institutions logically flow from the aforementioned observations and problems, including the observation that the simplification of the institutions is no simple task. The complexity has a reason and a history, and altering the institutions of Brussels along the lines of the present city may also lead to a further increase in complexity. However, it must also be possible to be able to think about the city without any taboos.

\section{The organisation of the elections}

The electoral system for the Brussels Capital Parliament strongly reflects past experiences and the fear that Dutch-speakers have of being underrepresented in the government. The result of this is a system with a democratic deficit. Redressing this is not so simple, especially when it involves guarantees for Dutch-speaking representation.

In principle, the problem of the non-representation of a large group of inhabitants that do not have the right to vote is easy to address. It suffices - even though this requires a change to federal legislation - for all inhabitants of the region that also have the right to vote in municipal elections to be able to use this right to vote in the elections for the Brussels Capital Parliament. In doing so, the group for who a hard electoral choice between one of the two language groups is not necessarily meaningful will then grow.

Addressing this is also not that simple. A number of possibilities are summarised here. The most radical change exists in abolishing the division in language groups for elections, making all lists available to all voters. However, this would also mean that protection for the Dutch-speakers would disappear. The elections for the regional parliament would then resemble municipal elections, in which Dutch-speakers can be elected from mixed-language lists, but with a representation that is much lower. It could also be decided to opt for incorporating a fixed quota, either for both language groups, or for a minimum number of Dutch-speakers. One alternative would be to also allocate a number of fixed seats to an 'open' or 'non-defined' group as well as having a fixed quota for the two language groups. However, this would once again disrupt the balances that are built into the joint composition of the Brussels Capital Region's government.

A different and 'softer" option would be to retain the layout of the lists in two language groups, but allocate all voters two votes, giving them the chance to transcend the separation of the language groups. This option would have the advantage that politicians would also need to take account of visions that are defended in a language group other than their own, but on the other hand, it would also serve to maintain the rigid separation between the two language groups. Due to the large number of French-speakers, relations between the Dutch-speaking parties would also be more strongly influenced by the French-speakers than the other way round. In this respect there are no cut and dried solutions available that do not immediately summon up a whole series of other questions and concerns. 


\section{Region and Communities}

The possibility of also bestowing the Brussels Capital Region with community powers needs to be looked into. Even though this would also not be easy and requires the federal constitution to be modified, bestowing community powers on the Brussels Capital Region would mean more of an addition from a community rather than the abolishment of the French and Flemish Communities. The Flemish Community will continue to make the rightful demand for policies affecting personal matters to be implemented in Dutch for those Brussels residents who wish for this (education, healthcare, arts). Services belonging to the Brussels community - particularly education - obviously can and must be multilingual. In other words, they should at least be bilingual, but also leave room for the other languages that have become today's languages of Brussels.

\section{Region and municipalities}

The Brussels Capital Region urgently requires thorough reflection about the place and meaning of the smaller units in a region that form a city, also providing an alternative interpretation to the notion of 'municipality' in Wallonia and Flanders. This debate needs to be carried out thoroughly, but also with the necessary caution. We must not forget that the smallest municipality within the Brussels Capital Region is larger in population terms than the average municipality in Flanders or Wallonia. Flemish Brabant has a similar sized population as the Brussels Capital Region and is divided into 65 municipalities whilst Walloon Brabant - with a third of the Brussels population - has 27 municipalities. This certainly puts the 'necessity' for reducing the number of Brussels municipalities - which is mainly defended on the Flemish side - into perspective.

It is also important not to lose sight of the fact that earlier amalgamations in urban environments have not been without problems. The amalgamation in Antwerp later led to districts being established. A number of perverse effects stemming from the amalgamation in Charleroi are also well known. Little distance between public services and citizens is not insignificant, just like between voters and their elected representatives. It is also difficult to ignore the fact that a significant proportion of the population - just as in Flanders and Wallonia - feel connected to the municipality in which they live.

Finally, it is important to reiterate that the debate will always be difficult due to its communautaire dimension, even though the Lombard Accord ensured a financial incentive for a much greater certainty of Flemish representation in the municipal councils.

However, Brussels now has the power to define and arrange the municipal level itself, just like the other regions. Today, questions are arising about the relations between the existing Region and the municipalities as well as about financial capacity with respect to the municipal level. The way in which both levels must and can be fulfilled remains open.

There are a variety of good examples of urban regions - including Berlin and Vienna - where the relation between city, region and smaller governing units are organised in a well considered way. To the outside world, the region must be able to speak 
with one voice, also in discussions with the other Belgian regions. Internally, there should be room for variation in policy and the provision of services.

Three related questions must also receive a concrete answer. The first concerns the meaning of the municipality itself, its task and powers, and complementing this, the task and powers that can be best fulfilled in the whole region, in the same way, by the regional government. The advantages and disadvantages of the principle of subsidiarity must also be kept in mind and we must not naively assume that no communautaire contrasts exist about these things, both within as well as outside Brussels.

The second question concerns the number and the borders of the municipalities. The present number and their borders are those of the villages that became a city, but they do not follow the lines that the urban development has followed, with the exception of the expansion of Brussels city. We have shown that this reflection is more than appropriate from a socio-economic, socio-geographic and socio-political standpoint.

Thirdly, there is the question concerning the way in which the municipalities can be governed. Thinking without taboos and without focussing too strongly on the old and trusted institutions and procedures would make it possible to develop a new type of municipality for the city region more creatively, in ways that involve citizens in a more intensive and more permanent way in a policy that directly relates to the organisation of the city and the provision of services where the residents of Brussels live.

\section{References}

DELWIT, P., REA, A., SWYNGEDOUW, M. (eds.), Bruxelles ville ouverte, Paris, L'Harmattan, collection Villes et entreprises, 2007.

WITTE, E., ALEN, A., DUMONT, H., VANDERNOOT, P. a DE GROOF, R. (eds) (2003), De Brusselse negentien gemeenten en het Brussels model / Les dix-neuf communes bruxelloises et le modèle bruxellois, Brussel / Bruxelles: Larcier

WITTE, E., ALEN, A., DUMONT, H. \& ERGEC, R. (eds) (1999), Het statuut van Brussel / Bruxelles et son statut, Bruxelles / Brussel: Larcier 


\section{Appendix}

\begin{tabular}{l|r|r|r|r} 
& $\begin{array}{c}\text { Surface area } \\
\text { in km2 }\end{array}$ & Population & $\begin{array}{c}\text { Population } \\
\text { density }\end{array}$ & $\begin{array}{c}\text { Welfare } \\
\text { index }\end{array}$ \\
\cline { 2 - 5 } Anderlecht & 17,7 & 99.085 & $5.286,70$ & 77 \\
\hline Oudergem & 9 & 30.086 & $3.239,60$ & 108 \\
\hline Sint-Agatha Berchem & 2,9 & 20.976 & $6.769,80$ & 102 \\
\hline Brussel & 32,6 & 148.873 & $4.381,20$ & 76 \\
\hline Etterbeek & 3,1 & 49.902 & $13.049,50$ & 82 \\
\hline Evere & 5 & 34.727 & $6.589,90$ & 88 \\
\hline Vorst & 6,2 & 48.906 & $7.611,10$ & 86 \\
\hline Ganshoren & 2,5 & 21.743 & $8.394,00$ & 101 \\
\hline Ixelles & 6,3 & 79.768 & $12.251,20$ & 87 \\
\hline Jette & 5 & 44.601 & $8.377,40$ & 94 \\
\hline Koekelberg & 1,2 & 19.020 & $15.114,20$ & 83 \\
\hline Sint-Jans-Molenbeek & 5,9 & 83.674 & $13.327,00$ & 65 \\
\hline Sint-Gillis & 2,5 & 45.235 & $17.321,80$ & 67 \\
\hline Sint-Joost ten Node & 1,1 & 24.078 & $20.259,20$ & 52 \\
\hline Schaarbeek & 8,1 & 116.039 & $13.559,60$ & 70 \\
\hline Ukkel & 22,9 & 76.732 & $3.272,60$ & 110 \\
\hline Watermaal-Bosvoorde & 12,9 & 24.134 & $1.880,00$ & 114 \\
\hline Sint-Lambrechts Woluwe & 7,2 & 49.261 & $6.622,30$ & 102 \\
\hline Sint-Pieters Woluwe & 8,9 & 38.651 & $4.284,10$ & 112 \\
\hline
\end{tabular}

Table 1: Surface area, population and welfare of the Brussels municipalities (2005) Source: National Institute of Statistics 